\title{
Effects of Credit Memos on Performance Accountant on Uncollectible Receivables
}

\author{
Qurotul Aini ${ }^{1}$, Rosdiana Simbolon ${ }^{2}$, Shylvia Ratna Dewi ${ }^{3}$ \\ ${ }_{1,2,3}$ Raharja University, JL. Jendral Sudirman No.40 Modern Cikokol Tangerang \\ e-mail: aini@raharia.info, rosdiana@aptisi.or.id, shylvia@raharia.info
}

\begin{abstract}
In the current era we have entered the disruptive 4.0 era where sophistication has been applied in the finance of a company to record every expense incurred by an institution or company. In the transaction process as it is now does not rule out the possibility of several triggers for making a deposit such as the example of a sales or purchase return and overpayment if it is not handled immediately it will arise as a financial report problem. The Cloud Accounting system is equipped with a credit memo facility which is divided into 2 (two) parts, namely customer memo credit and supplier memo credit. The Cloud Accounting system is then equipped with a credit memo facility which is divided into 2 (two) parts, namely customer memo credit and supplier memo credit. Where customer memo credit is the customer entrusting a sum of money to the company, it will be used as a payment on the upcoming sales bill. While supplier memo credit is the balance that arises due to overpayment, then the deposit will be used as a discount on future sales bills. By using a memo credit based on Cloud Accounting, it can minimize crime or crime at the company because it has been certified by ISO / IEC 2700.
\end{abstract}

Keywords: Online Accounting Software, Customer Memo Credit, and Supplier Memo Credit.

\section{Introduction}

In a large company like today it certainly will not be separated from economic activities such as monthly expenses and income. Various processes of recording both expenditure and income costs are of course very important for the company to provide accountability for the results of the report to the management so that a decision can be made.

In the accounting system the process of expenses and income costs is very important. This is because there are several triggers made deposits such as the results of sales or purchase returns and the existence of overpayments or so-called overpayments. By using the Web Based Accounting Online System there is a memo credit facility where this feature is used as a note if there is a deposit generated due to overpayment. According to Tan, K. E., and Sunarko, J. D. (2015), Credit memo is a source of documents that can be used as a basis for various records such as sales returns, recording a reduction in the amount of goods given to the customer concerned in a credit card [1].
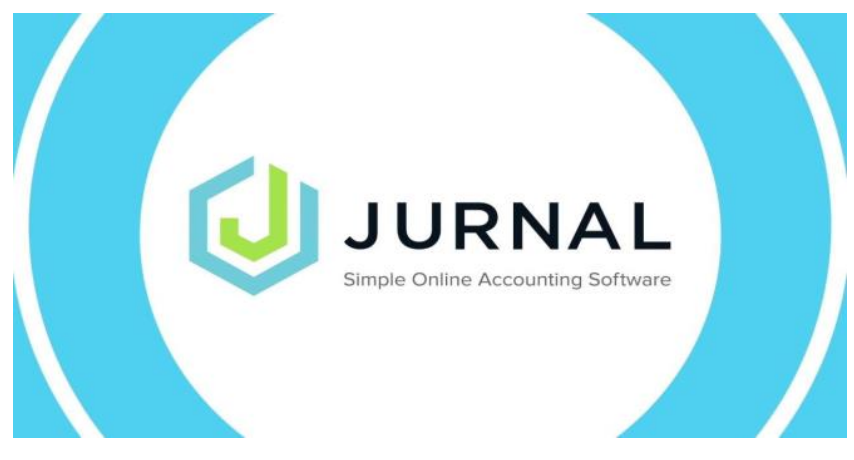


\section{Figure 1. Display of Web Based Accounting Online System}

In the Web Based Accounting Online System, the memo credit feature is divided into 2 (two) parts including customer memo credit and supplier memo credit. The definition of customer memo credit is that the company has a debt balance to the customer concerned, or in other terms the customer entrusts a sum of money to the company in the event that the sales invoice has not been issued or has not been billed. While supplier memo credit is the balance of debt arising from overpayments or deposits either done via transfer or cash supplier to companies that have not been paid [2].

\section{Research Method}

In carrying out the design and development of a system there are several very important things that must be considered, including there are research methods to solve various formulations of problems that exist in this research stage.

In this study using several research methods including observation techniques, interviews, and Literature Review. The observation technique has been carried out directly by monitoring the deposit balance of customers in the company.

\section{Literature Review}

According to Rahardja, U. (2016), Literature Review is written material both in the form of books and sources from previous research, discussing the subject of journals or scientific works with topics to be researched relevant to previous or existing research topics. Due to the previous research there have been many scientific studies that have conducted research on the credit credit feature to minimize deposits and uncollectible receivables [3].

1. Research conducted by Rahardja, U., Aini, Q., and Hardini, M., (2018), entitled "Application of Online Accounting Software as a Support for Recording Financial Reports". This study reviews a sales recapitulation system based on Online Accounting Software to facilitate accountants in inputting transaction data in the system, where transaction data can be automatically synchronized or directly imported into the Online Accounting Software system so that it is more effective and efficient. Besides that another perceived advantage is that it is considered to be able to reduce the amount of paper usage in order to make financial statements in the event of a transaction error. In addition, transaction data stored in the system is very good security so that the confidentiality of the data is ensured well stored on the system [4].

2. Research conducted by Yusup, Rahardja, U., and Oktaviani, S., (2014), entitled "GO + in Supporting INT + For Management of CMB Data in Higher Education" This study reviews a system that is used online as supporting data management New Student Candidate (CMB). There are 3 (three) objectives, including the first goal, namely to increase the promotion or marketing activities of the Higher Education for New Student Candidates, the second goal is to support the management of the new Student Candidate's personal data in the form of names, emails and telephone numbers of New Student Candidates, then the third goal is in order to facilitate both parties both Marketing and New Student Candidates so as to improve the performance of Marketing Division personnel [5].

3. Research conducted by Fitriani, N., and Irmayanti, E., (2018), entitled "Analysis of Accounting Systems for Receivables and Uncollectible Receivables to Improve the Effectiveness of Internal Control in PT Semen Indonesia Logistik Cabagn Tulungagung". This study reviews a system that has 4 (four) objectives, namely to find out the accounts receivable and uncollectible accounting, then to find out and as an internal control of accounts receivable and uncollectible receivables, and the third goal is to find out the effectiveness of internal control, the final goal is to improve internal control that will be implemented in PT Semen Indonesia Logistik Branch Tulungagung. In the development of this system the researcher uses 2 (two) 
methods of research namely qualitative research and approaches using the COSO model. Then consists of 4 (four) data collection techniques namely interviews, questionnaires, documentation and also observations [6].

4. Research conducted by Rahardja, U., Aini, Q., and Thalia, MB, (2018), entitled "Application of Confirmation Menu for Yii-Based Online Payment in Higher Education" This study reviews a system in which payment confirmation forms have facilities on Universities with Yii Framework 2 based on CRUD (Create, Read, Update, Delete) feature which has the function of facilitating two parties, namely the cashier and also the students. Then in addition there are 3 (three) advantages that can be produced, namely the first on the menu facility payment confirmation form designed with a website-based so as to facilitate the user in accessing, then the second advantage is that there are several payment method options equipped with the number of payment bills making it easier to make transactions and the third advantage is the availability of an input menu or bill invoice so that the data inputted by the user can be guaranteed the truth [7].

5. Research conducted by Kawan, J. C., Chu, R. K. H., and Tompkins, P., (2018), entitled "Method and System for Controlling Certificate Based on Open Payment Transactions". This study reviews a system and method for controlling certificate-based payment transactions involving two parties, namely traders and customers using various types of networks and terminals. The initial step before the customer accesses the merchant's POS terminal, such as an example of a merchant's website, the customer obtains a certificate from the service provider (SP), such as a bank that can state identification (ID) and also provide relevant or relevant financial information. Service providers (SP) can perform various functions, with examples being able to act as certificate authorities when in the process of issuing a customer certificate, then functioning as an authenticator when the customer receives a private key encrypted certificate from the customer to be decrypted using the associated public key [8].

6. Research conducted by Jobst, A. A., (2018), entitled "Credit Risk Dynamics of Infrastructure Investment: Considerations for Financial Regulators". This study examines a prudential system of infrastructure investment which has an important role to mobilize finance in the long term from institutional investors, with examples of insurance companies to provide support for sustainable development. In infrastructure projects, they are asset-dense, resulting in a stable and long-term cash flow. So the company provides a natural fit for investment strategies driven by insurance entities. There is an experience of default which can be seen in historical or records of infrastructure debt which shows the "hump-shaped" credit risk profile blends with investment grade quality within a few years after the financial closes. And it is supported by consistently high recovery rates so that variation across countries is limited on non-accruals. Capital cost revenue will decrease significantly in order to treat different regulations of infrastructure debt as a separated asset class [9].

7. Research conducted by Bisbee, S. F., Caporlette, B. K., Attinello, A. J., and Daly, V. F., (2018), entitled "Systems and Methods for Electronic Deposit and Authentication of Original Electronic Information Objects". This study reviews a system and method for depositing safely and reliably using a trusted repository system. The object that is executed is the authoritative information object using an electronic signing system that is carried out by a third party. And maintained in a storage system that has received real information objects from third parties, third parties also have responsibility in signing electronic systems so that TRS can facilitate electronic transmission, storage and return of verified copies of authenticated information objects authenticated without TRS to release responsibility for authenticated information objects [10].

8. Research conducted by Sharma, S., and Mehra, V., (2018), entitled "Default Payment Analysis of Credit Card Clients". This study reviews an exercise in analyzing the performance of various algorithm formulas to calculate the risk of customers who fail to make payments using a credit card. The performance of the algorithm is that it can be measured using a variety of metrics which can detect credit card fraud or default which is a complicated problem 
in terms of business perspective. To get the maximum (True Positive) defaulters and minimize false positives can make selection based on accuracy does not make sense because the data set is not balanced and has a slope. Therefore sensitivity or commonly referred to as True Positive Rate is very important. The correct model is a balance between high memory and reasonable precision. Thus, the F-Measure and ROC curves are metrics that can be used together with Precision and Recall. This system can certainly help the bank make a decision based on accurate information. For example, all features need to be included in a customer's credit card in order to issue a credit card or assess eligibility and repay one's capacity [11].

\section{Results and Analysis}

In the previous problem, there were several students who left some money due to overpayment to the cashier, then the money that had become the deposit would be used as a repayment on the next semester payment bill. Then you can use the memo credit feature with the steps in the following implementation results.

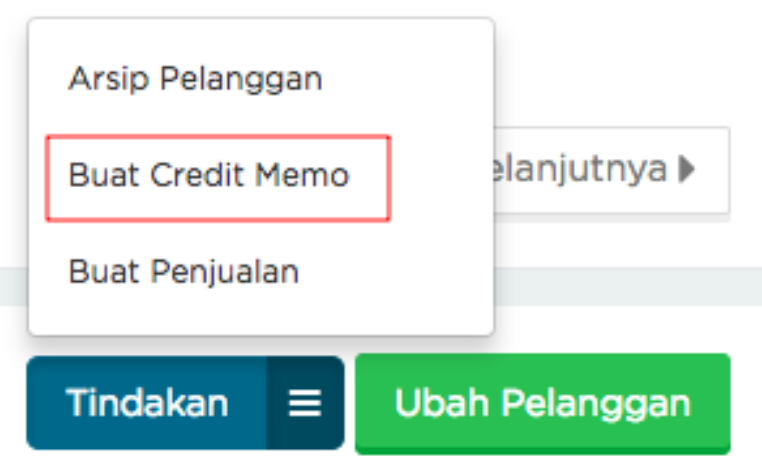

Figure 2. Initial Display of Memo Credit

The picture above explains the initial step in making a memo credit, which can be done by selecting the "Customer" menu after entering the customer menu. The next step is to click or press one of the names of customers who have a deposit. "Which has 3 (three) facilities, namely" Customer Archive "," Create Sales "and can be done click the Create Credit Credit button. which is conducted. and the "Create a New Cost" button to save the cost data you just created.

According to En, T. K., Massie, J. M., and Carolina, V., (2014), uncollectible receivables are if the receivables that are far past their maturity date. An uncollectible receivable is a loss suffered by the company and must be recorded as an expense or expense in an income statement [12].

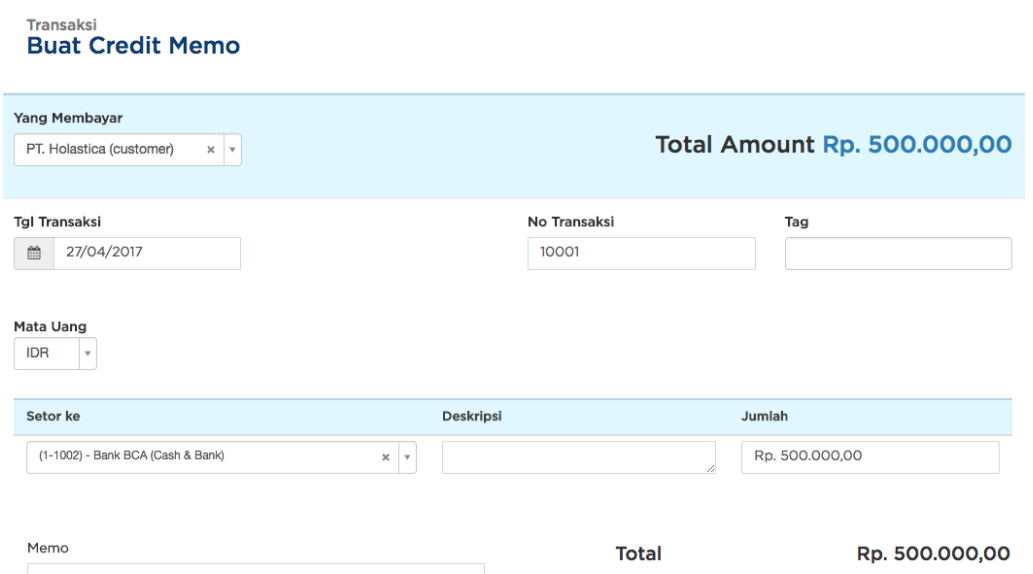

Figure 3. Form for Making a New Memo Credit 
In Figure 3, there is a form in making a new memo credit with some fields that must be completed in the blank column that has been provided. So it's similar to research that has been done before. In the transaction date column, it can be filled in according to the date of the new memo credit making transaction. Then switching to the deposit column can be done, select "BCA Bank" account. The next step in the nominal credit memo can be filled in according to the amount of balance deposited with the company or deposit. After all stages and processes are complete, you can click "Create" to save the credit memo you just made [13].

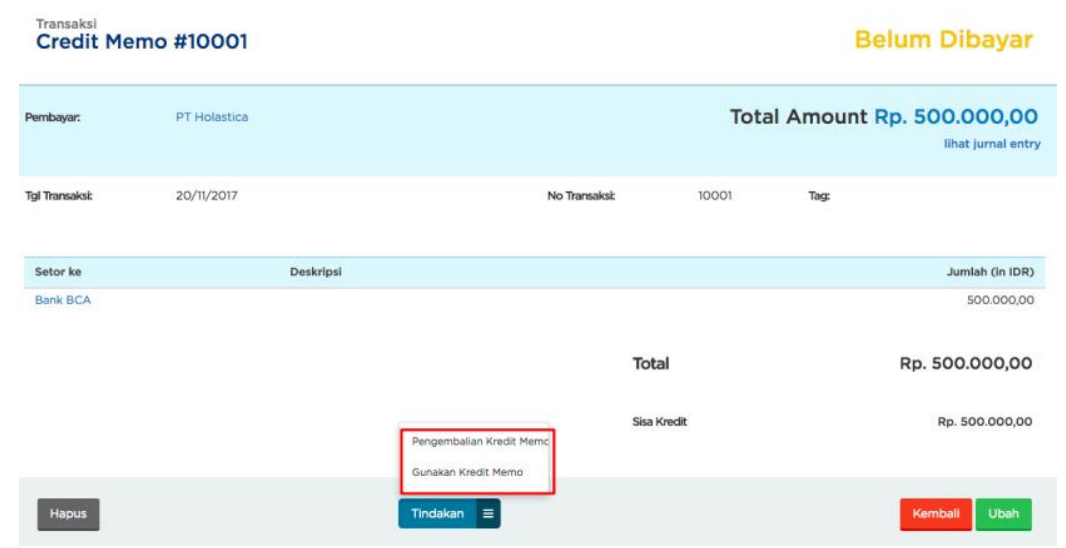

Figure 4. Display of Memo Credit Has Been Successfully Created

In Figure 4, it has been explained that if the memo credit is successfully saved, the display will look like above. Then, at the bottom position there is an action button which has 2 (two) choices, namely a credit memo return and an option to use a memo credit. Definition of Returns Credit memos are repayments made to invoices for bills or sales of the company concerned and occur if the invoice has been made by the Online Accounting Software system. And the definition of using memo credit is the return of deposit money to customers who have been deposited before [14].

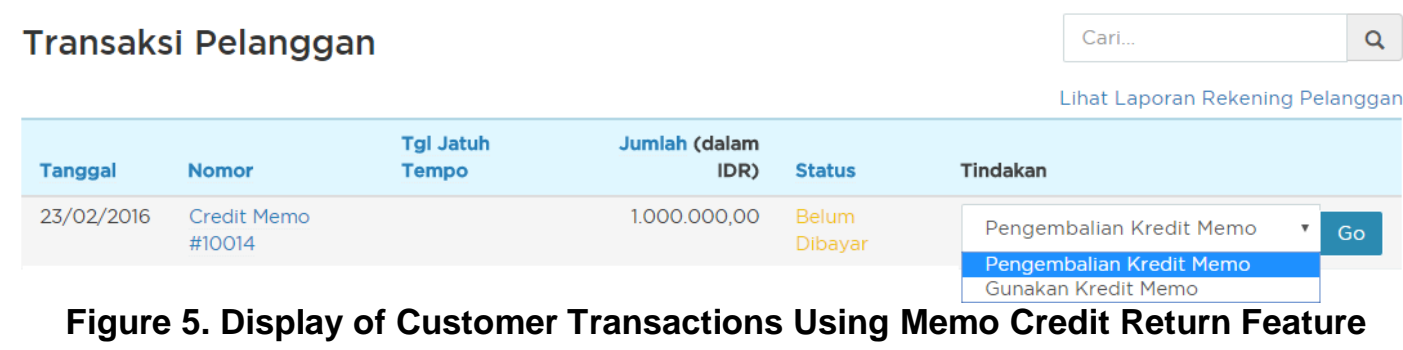

As the researcher discussed earlier about there are 2 (two) choices on the action menu, namely the return of the memo credit and using the memo credit. So the first step when you want to make a memo credit return is that you can visit the customer menu on the system, then click the name of the customer who has the previous memo credit. Scroll through the page until the end and will be seen in the Transaction section of the customer as shown above. Next to the final step press in the action column. To use the memo credit repayment that has been made beforehand, select "Credit Return memo" and do click "Go" [15]. 


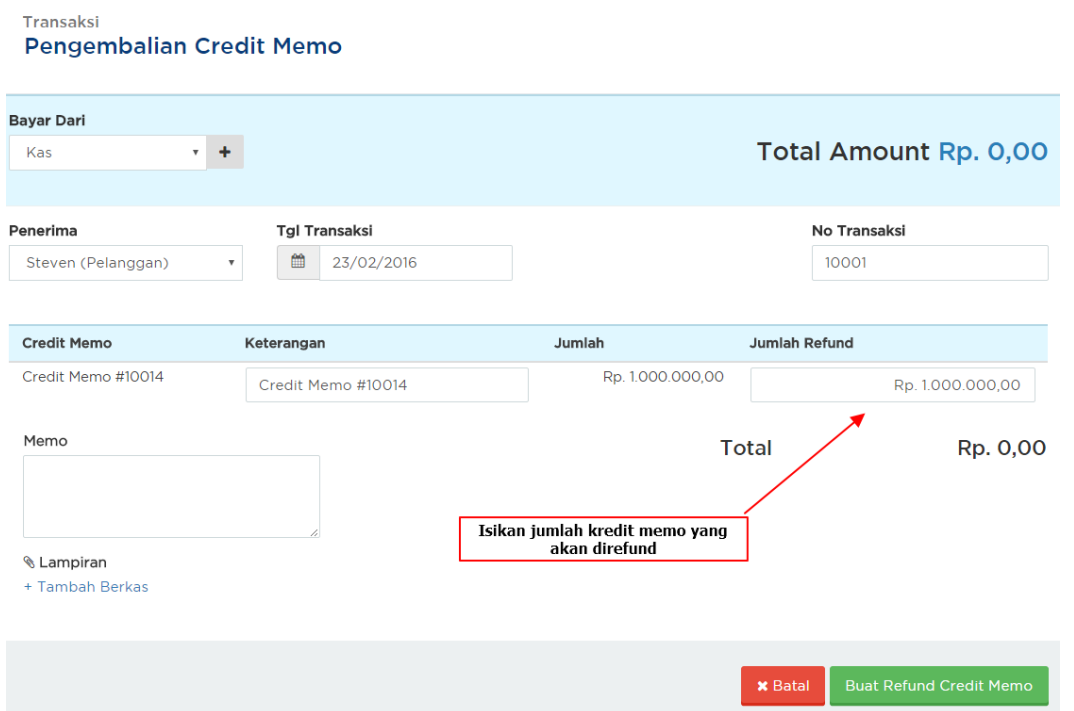

Figure 6. Credit Memo Return Form

In the above view the researcher explains the return of the credit memo by selecting the field for the refund amount then entering the total balance that will be returned to the customer. can be seen in the 7 (seven) field explanations as follows:

a. Choose from which account to pay for memo credit in the "Pay From" field.

b. "Recipient" memo credit will appear according to the customer you choose.

c. Select the date you use the credit memo in the "Transaction Date" field.

d. "Transaction Number" will be given and sorted automatically by the system. However, you can also change it as desired.

e. Give additional "Description" if needed in the Remarks column;

f. Fill in the amount that will be reimbursed, it can be in accordance with the number of existing or partial memo credits;

g. Click "Create Credit Memo Refund" to process.

According to Tiara K., Nurhaeni T., and Faradisa Y., (2017), Write off Memo is the source of the document for the basis of recording in the elimination of accounts. The accounting division has the responsibility to issue this document in order to authorize the elimination of accounts receivable that cannot be reimbursed. But the researchers gave a suggestion that there are several other parts that have independent properties [16]. 


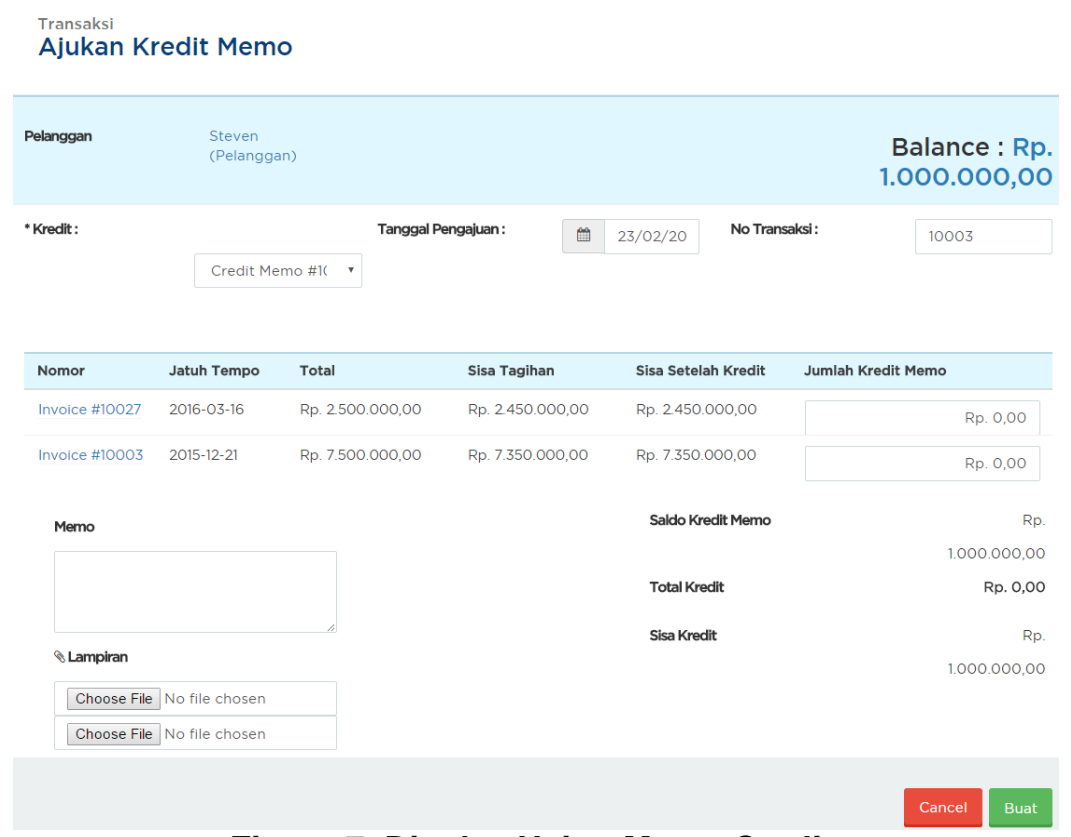

Figure 7. Display Using Memo Credit

In Figure 7 , there are facilities for using memo credit. Where, the initial step can be done, select the memo credit that will be used. Then, in the filing date field can be filled in the date when using the memo credit. The next step, the transaction number will be sorted automatically by the Online Accounting Software system but there are facilities to change if you want to change as desired. In the most important part, which is to fill in the number of credit memos that will be used, if you have more than 1 bill for 1 customer, then you can choose the invoice that will be deducted using the memo credit. The last step, click the "Create" button then use the memo credit after processing [17].

\section{Transaksi Pelanggan}

\begin{tabular}{|c|c|c|c|c|c|c|c|}
\hline & & & & & Lihat Laporan Reh & $\mathrm{Pe}$ & angg: \\
\hline Tanggal & Nomor & $\begin{array}{l}\text { Tgl Jatuh } \\
\text { Tempo }\end{array}$ & Jumlah & Status & Tindakan & & \\
\hline $20 / 11 / 2017$ & Credit Memo \#10001 & & Rp.500.000,00 & Belum Dibayar & Pengembalian Kredit Memo & $\hat{\nabla}$ & Go \\
\hline 28/04/2017 & $\begin{array}{l}\text { Sales Invoice } \\
\text { \#JP10005/2017 }\end{array}$ & $28 / 05 / 2017$ & Rp. $1.000 .000,00$ & $\begin{array}{l}\text { Lewat Jatuh } \\
\text { Tempo }\end{array}$ & Lihat Faktur & $\hat{\nabla}$ & Go \\
\hline
\end{tabular}

Figure 8. Display of Customer Transactions To Use Removing Credit Memo

In figure 8, the researcher explains that if a credit or debit memo has been made beforehand and an error has occurred, it must be changed or even deleted. So the accountant in the company can do both facilities with the first step, namely selecting the "Customer" menu after that scrolls the customer's display until the end and can click on "Credit Memo" transactions on this cloud accountingbased system. 


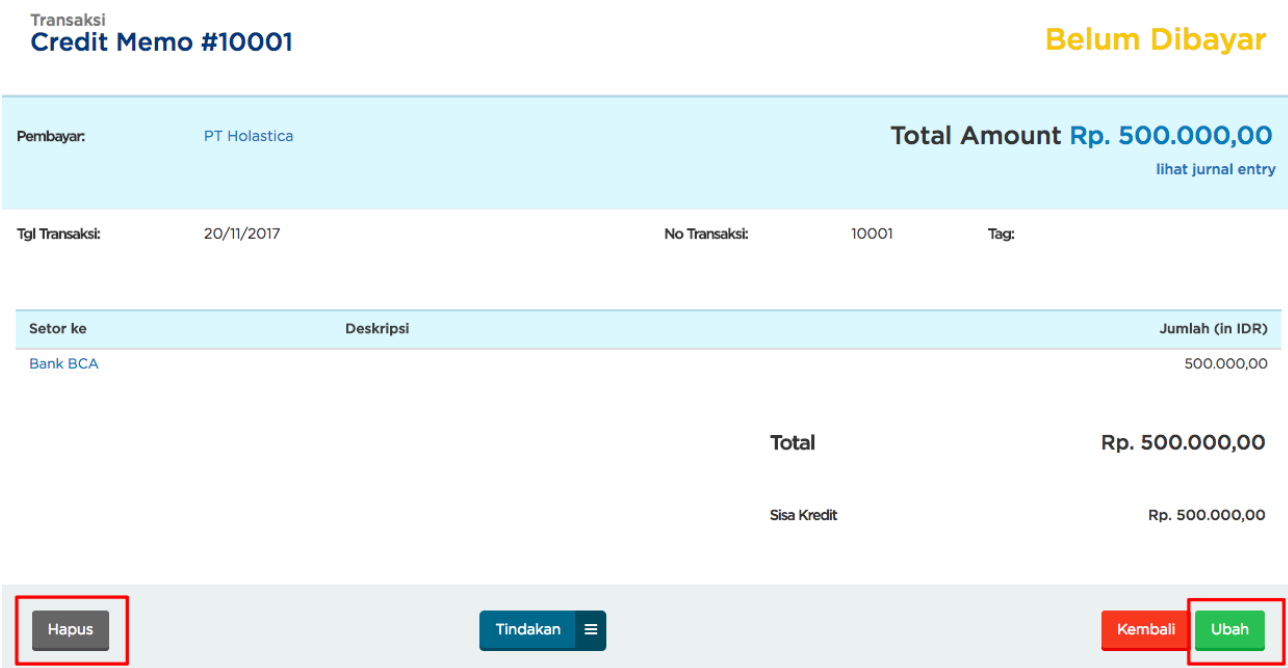

Figure 9. Display of Delete Credit Memo Facility

Then, to delete the credit memo facility, you can click "Change" in the lower right corner position to change the credit memo that was made before but an error occurred. Or you can press the "Delete" button with the position of the lower left corner to delete the credit memo that was previously made [18].

According to Manurung, EBP, Ariessanti, HD, and Destrianti, DI, (2017), cloud accounting systems also use CRUD (Create, Read, Update, and Delete) systems so that changes can be made to the costs that have been previously made and can remove costs. if an error occurs in the previous input. The Cloud Accounting system has been certified by ISO / IEC 2700 so that the security of the security report is equivalent to that of a bank [19].

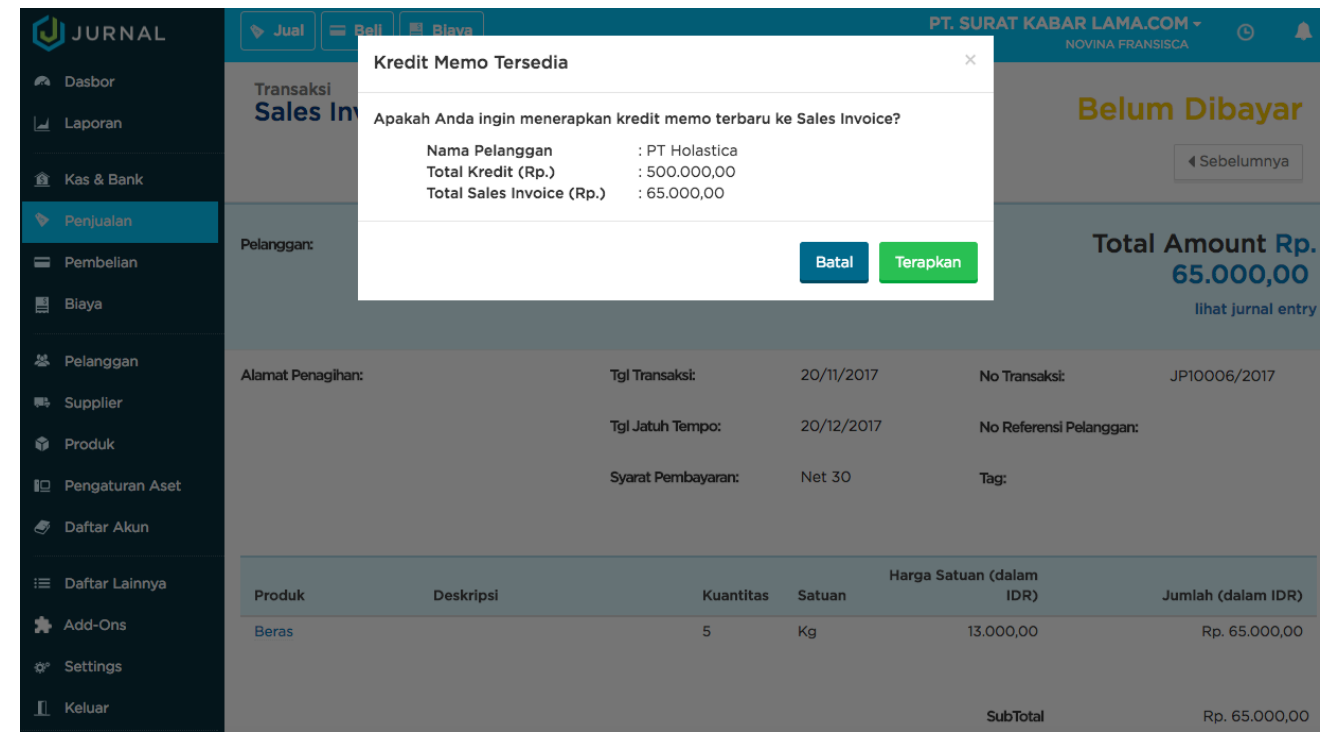

Figure 10. Display of Top Up of Customer Memo Credit

Equally important, if the accountant wants to do the facility to change and delete the memo credit, then it is necessary to synchronize customers who have memo credit and do not have memo credit. If the credit memo has been successfully created and processed, when the customer wants to 
make a payment and there is a credit memo, the message will appear as top up as the researcher explained in the picture above.

\section{Conclusion}

From the entire discussion described above, the authors can draw the conclusion that, in the accounting cloud system there are several credit memo features which can facilitate the accountant in returning the deposit or overpayment or the results of sales or purchase returns. Then in this system is equipped with a CRUD system (Create, Read, Update, Delete) changes and deletes the credit memo that has been made before but there is an error that makes it easy for both parties, namely the accountant and the customer on the finance of a company finance.

\section{References}

[1] Tan, K. E., \& Sunarko, J. D. (2011). Peranan Sistem Informasi Akuntansi Penjualan Untuk Meminimalisasi Piutang Tak Tertagih (Studi Kasus Pada Perusahaan Sepatu" X"). Akurat Jurnal IImiah Akuntansi, 2(05).

[2] Rahardja U, Aini Q, Enay N. Optimalisasi Dashboard pada Sistem Penilaian Sebagai Media Informasi di Perguruan Tinggi. Sisfotenika. 2017 Aug 21;7(2):167-76.

[3] Rahardja, U., Tiara, K., \& Rosalinda, I. A. (2016). Pemanfaatan Google Scholar Dan Citation Dalam Memenuhi Kebutuhan Pembuatan Skripsi Mahasiswa Pada Perguruan Tinggi. Technomedia Journal, 1(1), 95-113.

[4] Rahardja, U., Aini, Q., \& Hardini, M. (2018). PENERAPAN SOFTWARE AKUNTANSI ONLINE SEBAGAI PENUNJANG PENCATATAN LAPORAN KEUANGAN. SISFOTENIKA, 8(2), 176-187.

[5] Yusup, M., Rahardja, U., \& Oktaviani, S. (2014). GO+ Dalam Menunjang Int+ Untuk Pengelolaan Data Cmb Pada Perguruan Tinggi. CCIT Journal, 8(1), 65-82.

[6] Fitriani, N., \& Irmayanti, E. (2018, September). ANALISIS SISTEM AKUNTANSI PIUTANG DAN PIUTANG TAK TERTAGIH UNTUK MENINGKATKAN EFEKTIVITAS PENGENDALIAN INTERNAL PADA PT SEMEN INDONESIA LOGISTIK CABANG TULUNGAGUNG. In Seminar Nasional Manajemen Ekonomi Akuntansi (Vol. 2, No. 1, pp. 57-62).

[7] Rahardja U, Aini Q, Thalia MB. Penerapan Menu Konfirmasi Pembayaran Online Berbasis Yii pada Perguruan Tinggi. Creative Information Technology Journal. 2018 Mar 22;4(3):174-85.

[8] Kawan, J. C., Chu, R. K. H., Golvin, C., \& Tompkins, P. (2018). U.S. Patent No. 9,928,491. Washington, DC: U.S. Patent and Trademark Office.

[9] Jobst, A. A. (2018). Credit Risk Dynamics of Infrastructure Investment: Considerations for Financial Regulators (Report Version).

[10] Bisbee, S. F., Caporlette, B. K., Attinello, A. J., \& Daly, V. F. (2018). U.S. Patent Application No. 15/764,509.

[11] Sharma, S., \& Mehra, V. Default Payment Analysis of Credit Card Clients.

[12] En, T. K., Massie, J. M., \& Carolina, V. Pengembangan Sistem Informasi Akuntansi Penjualan Kredit untuk Meminimalisasi Kerugian atas Piutang Tak Tertagih.

[13] Sudaryono, S., Sunarya, L., \& Maulani, G. (2017). Facility for Customizing Transaction Forms on Master Data Using an Online Accounting System Web For Work Efficiency Company. Aptisi Transactions of Management (ATM), 1(1), 19-26.

[14] Sunarya, A., Rafika, A. S., \& Rahayu, S. (2017). Analyze and Record a series of Purchase Transactions on Companies using Online Accounting Software. Aptisi Transactions of Management (ATM), 1(1), 42-47.

[15] Sunarya, A., Saptoro, A., \& Apriyani, D. (2017). Utilization Setting Menu To Build Company Accounting System In Web Based Accounting Online System. Aptisi Transactions of Management (ATM), 1(1), 1-10. 
[16] Tiara K, Nurhaeni T, Faradisa Y. PENERAPAN GO+ BERBASIS WEB UNTUK MENINGKATKAN MUTU PELAYANAN LEMBAGA KEUANGAN MAHASISIWA. Technomedia Journal. 2017 Mar 1;1(2):90-105.

[17] Azizah, N., Suryana, E., \& Haris, H. (2017). Application of a Customer Based Data Monitoring Facility Online Accounting Software For Effectiveness Leadership at Higher Education. Aptisi Transactions of Management (ATM), 1(2), 93-100.

[18] Aini, Q., Rahardja, U., Madiistriyatno, H., \& Setiaji, Y. D. M. (2018). Pengamanan Pengelolaan Hak Akses Web Berbasis Yii Framework. Syntax Jurnal Informatika, 7(1), 52-63.

[19] Manurung, E. B. P., Ariessanti, H. D., \& Desrianti, D. I. (2017). Implementation of Recording System Regular Spending Cost Based Software Online Accounting For Record Expenditures on the Company. Aptisi Transactions of Management (ATM), 1(2), 123-130.

[20] Rahardja, U., Aini, Q., \& Santoso, N. P. L. (2018). Pengintegrasian YII Framework Berbasis API pada Sistem Penilaian Absensi. SISFOTENIKA, 8(2), 140-152.

[21] Rahardja, U., Aini, Q., \& Khoirunisa, A. (2017). Implementasi Business Intelligence Menggunakan Highchart pada Sistem Penilaian Absensi berbasis YII Framework. CSRID (Computer Science Research and Its Development Journal), 9(2), 115-124.

[22] Yusup, M., Padeli, P., \& Ilamsyah, I. (2017). General Journal Recording System Analysis In Companies using Online Accounting Software. Aptisi Transactions of Management (ATM), 1(1), 54-59.

[23] Sharma, S., \& Mehra, V. Default Payment Analysis of Credit Card Clients. 